\title{
INTERPRETATION OF FIELD OBSERVATIONS IN THE SOUTHERN PART OF THE ILÍMAUSSAQ INTRUSION, SOUTH GREENLAND
}

\section{Aelita Demin}

During the 1971 field work mapping at the scale of 1:10000 was continued in the area of Kangerdluarssuk fjord (see Demin, 1971). The most important field observations arising from the mapping are interpreted below. These notes should be viewed in the light of the earlier work on naujaite and lujavrites in the Ilímaussaq intrusion (see references in the text and Ferguson, 1970).

(a) The lower portion of the green aegirine lujavrite has been formed under strong pressure and increasing temperature caused to a great extent by reworked naujaite. Features of assimilation of the naujaite (Sørensen, 1958) are present throughout the area mapped; the arfvedsonite poikilocrysts in the lujavrite close to the naujaite appear to be remobilised poikilitic arfvedsonite of the original naujaite.

(b) The coarse-grained, lens-shaped inclusions, both the light-coloured pegmatitic as well as fine-grained horizons characterising the lower part of the aegirine lujavrite, represent partially assimilated naujaite remobilised within the younger rock.

(c) The coarse-grained lujavritic rock, which occurs on the north-west slope of the ridge at the head of Kangerdluarssuk fjord as a transition between the finer grained aegirine lujavrite and the pegmatitic series, together with lens-shaped horizons usually connected with, or confined to the naujaite, represents lujavritised naujaite.

(d) The black arfvedsonite lujavrite contains older rock material close to the intrusive contacts with the naujaite and, in the lowermost portion, green lujavrite. The segregation rocks (Demin, 1971) composing the lower, thin, black lujavrite apophyses in the green lujavrite or developed in contact with this rock and with naujaite, have been formed through mineral differentiation of a new melt and reworked older rocks. However, the arfvedsonite lujavrite proper with laminar texture has been formed through gradual transition from the aegirine lujavrite (Ferguson, 1964). The transitional fine- to coarse-grained rocks have a kakortokitic appearance.

(e) The "breccia zone" (Ussing, 1912; Sørensen, 1958, 1962) has been formed in situ by intrusion of lujavrite into naujaite preferentially along a jointing which caused a separation of the naujaite into blocks. Usually a thin layer of green lujavrite is developed as a zone of alteration between the black lujavrite and naujaite in conformity with the shape of the contacts.

(f) Lujavrite also forms dykes and thin veins in the naujaite being common along joints and in the naujaite pegmatites. The jointing in the naujaite has 


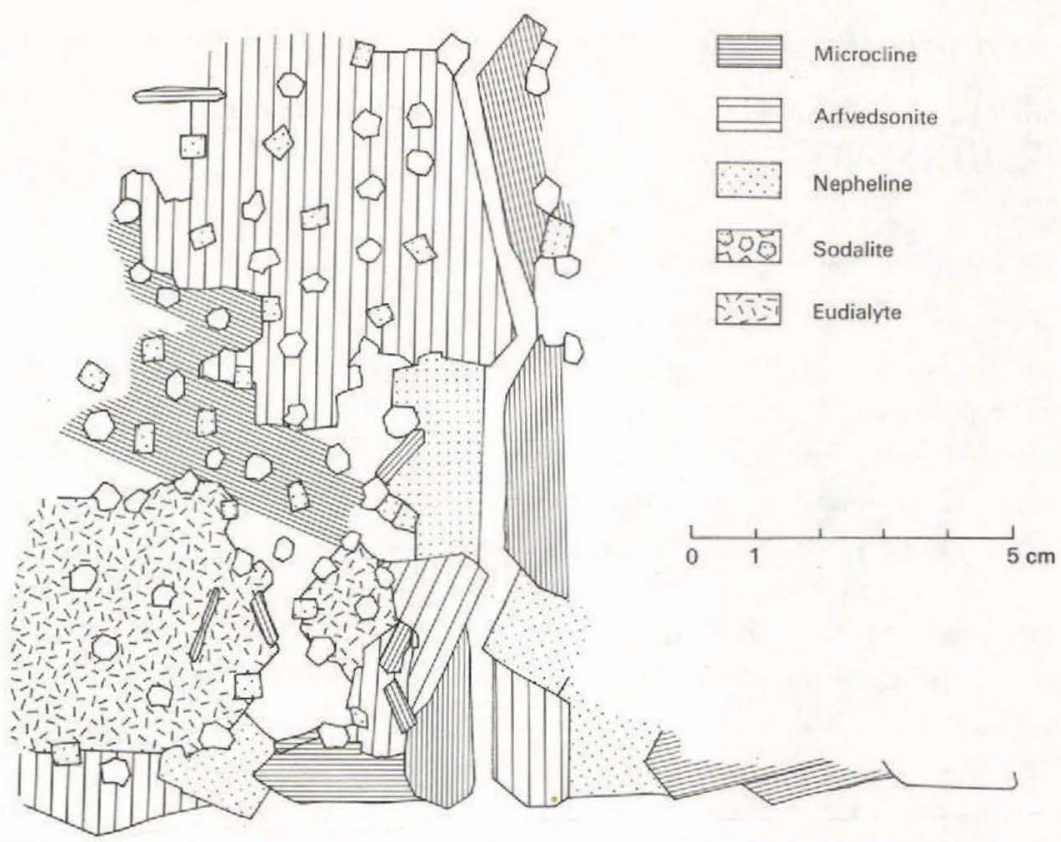

Fig. 5. Sketch showing detail texture of eudialyte-free naujaite pegmatite within naujaite. (Demin).

developed during the crystallisation of the rock with the formation of thin, up to 4 $\mathrm{cm}$ eudialyte-free pegmatites (fig. 5). These pegmatites are often superimposed by lujavrite veins. The black lujavrite apophyses in the naujaite pass into veins and a rock similar to the medium-grained lujavrite of Kvanefjeld (Sørensen et al., 1969). In places these black veins appear to follow older green lujavrite veins.

(g) The majority of the white pegmatitic veins and bands in the lujavrites, as well as contact pegmatites between these rocks and naujaite can be demonstrated to be reworked naujaite.

(h) The rare earths mineralisation is mainly connected with the upper part of the green, and the lower part of the black lujavrites, being especially rich in the actual alternation zone between these rocks. The most typical mineral here is steenstrupine. Tugtupite, chkalovite, astrophyllite, pyrochlore, "white $\mathrm{Nb}$ mineral"(?) (Semenov, 1969), a complex sulphide and apatite have also been found.

\section{References}

Demin, A. 1971: Detailed mapping in the southern part of the Ilímaussaq intrusion (Kangerdluarssuk fjord). Rapp. Gronlands geol. Unders. 35, 29-30.

Ferguson, J. 1964: Geology of the Ilímaussaq alkaline intrusion, South Greenland, Bull. Grønlands geol. Unders. 39 (also Meddr Grønland 172, 4), 82 pp. 
Ferguson, J. 1970: The differentiation of agpaitic magmas: the Ilímaussaq intrusion, South Greenland. Can. Miner. 10, 335-349.

Semenov, E. I. 1969: Mineralogy of the Ilimaussaq alkaline massif (South Greenland). Moskva: 'Nauka'. (in Russian).

Sørensen, H. 1958: The Ilímaussaq Batholith. A review and discussion. Bull. Grønlands geol. Unders. 19 (also Meddr Grønland 162, 3), 48 pp.

Sørensen, H. 1962: On the occurrence of Steenstrupine in the Ilimaussaq massif, Southwest Greenland. Bull. Grønlands geol. Unders. 32 (also Meddr Grønland 167, 1), $251 \mathrm{pp}$.

Sørensen H., Hansen, J. \& Bondesen, E. 1969: Preliminary account of the geology of the Kvanefjeld area of the Ilímaussaq intrusion, South Greenland. Rapp. Gronlands geol. Unders. 18, $40 \mathrm{pp}$.

Ussing, N. V. 1912: Geology of the country around Julianehaab, Greenland. Meddr Grønland $38,376 \mathrm{pp}$.

\section{GEOLOGICAL AND GEOPHYSICAL WORK ON ULTRAMAFIC ROCKS IN THE NANORTALIK AREA, SOUTH GREENLAND}

\section{Hans K. Schönwandt}

The detailed investigation of various ultramafic intrusions in the Nanortalik area started in 1969 (see Schönwandt, 1971) was continued in 1971. During July and August field groups led by the present author, Kai Sørensen (Geol. Inst., Univ. Aarhus) and Niels Abrahamsen (Lab. Geofysik, Univ. Aarhus) carried out geophysical and prospecting programmes concerned with the mineralisation (nickel, copper, platinum etc.) of the ultramafic rocks.

The ultramafic body on Amitsoq (see Berrangé, 1970) was subject to renewed and more accurate magnetic measurements and the same area was covered by an electromagnetic programme. The measurements obtained have not yet been completely interpreted but it has become clear that two magnetic anomalies exist in the central covered part of the body. In connection with these smaller electromagnetic anomalies occur.

A magnetic survey was also carried out in a valley about $4 \mathrm{~km}$ south of the main ultramafic body where ultramafic blocks were found. No additional anomalies were discovered and it must be assumed that the origin of the boulders is the main pluton.

Tracing of boulders has however helped in the discovery of a hitherto unknown ultramafic body on the south coast of Sermilik fjord. This body is continually exposed along the coast for $200 \mathrm{~m}$ and can be traced inland for about $350 \mathrm{~m}$. A group of smaller exposures of the same rock type exists about $2 \mathrm{~km}$ south-east along 